\title{
Ameliorative role of tannic acid on monosodium glutamate- induced pancreatic toxicity on albino rats
}

\author{
Palkis A. Mohamed ${ }^{1}$, Sherine A. Mohammed ${ }^{2}, \operatorname{Rania}$ A. $\operatorname{Radwan}^{1}$, and Soheir A. Mohamed ${ }^{1}$.
}

\begin{tabular}{|c|c|}
\hline & ABSTRACT \\
\hline $\begin{array}{l}\text { KEYWORDS } \\
\text { Monosodium glutamate; } \\
\text { Pancreatic toxicity, } \\
\text { Tannic acid, } \\
\text { Histopathology }\end{array}$ & $\begin{array}{l}\text { Monosodium Glutamate (MSG) is a widely used food additive that has } \\
\text { several deleterious effects on different body organs. Tannic acid (TA) is a naturally } \\
\text { occurring antioxidants with several pharmacological properties. The present study } \\
\text { was designed to study the toxic effects of MSG on the pancreas with the possible } \\
\text { ameliorative role of TA. Forty male albino rats were used in this study in the form of } \\
\text { four groups, } 10 \text { rats each. Group I, was the control group, fed on the standard diet, } \\
\text { Group II received TA (100mg/kg), Group II received MSG (2g/kg) and Group IV } \\
\text { received TA and MSG orally by gavage for } 4 \text { weeks. Biochemical analysis revealed } \\
\text { that MSG affected the pancreatic function by a significant increase in the serum } \\
\text { levels of amylase and lipase enzymes, as well as, the blood sugar level }(\mathrm{p}<0.001) \\
\text { meanwhile it did not significantly affect plasma insulin level (p>0.05). } \\
\text { Histopathological examination showed severe destruction in the pancreatic } \\
\text { architecture with hypertrophy and hyperplasia in the pancreatic islets as well as a } \\
\text { decrease in the number of acinar cells in addition to congestion and dilation in the } \\
\text { blood vessels. Co-administration of TA with MSG attenuated these effects; this role } \\
\text { may be explained by its anti-oxidative effects that need future research to explain the } \\
\text { mechanism of action. It is concluded that MSG has a deleterious effect on the } \\
\text { pancreas functionally and morphologically and TA act as a good antioxidant agent } \\
\text { against MSG toxicity. }\end{array}$ \\
\hline
\end{tabular}

\section{Introduction}

Monosodium glutamate (MSG) is a widely used food additive that is added to packaged foods as a flavor enhancer (Sharma and Deshmukh, 2015; Bera et al., 2017; Shukry et al., 2020).

Although the food and drug Administration (FDA) stated that MSG is a safe substance, several studies showed that MSG is found to be toxic and cause different

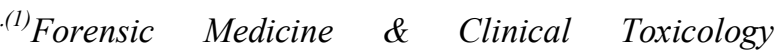
Department, Faculty of Medicine, Suhag University, Suhag, Egypt.

${ }^{(2)}$ Histology Department, Faculty of Medicine, Sohag University, Sohag, Egypt.
}

health problems in humans and experimental animals (Waer and Edres, 2006; Husarova and Ostatnikova, 2013; Butnariu and Sarac, 2019).

The pancreas is one of the organs which may be affected by many toxins. However, few reports that studied the effect of MSG on the pancreas which resulted in a scarcity of information on exocrine functions (Kumar et al., 2015 and Abdulsalam et al., 2018).

Many natural components are working against reactive oxygen species and oxidative stress through their anti-oxidant properties, for example, vitamins $\mathrm{C}, \mathrm{E}$, polyphenolic, and quercetin compounds (Bertolin et al., 2011). 
Tannic acid (TA) is a plant-derived polyphenol found in the bark and fruits of many plants such as tea, coffee, grapes, and nut. It is a natural antioxidant that quenches lipid peroxidation, prevents DNA oxidative damage, and scavenges hydroxyl radical $(\mathrm{OH})$ (Omar et al., 2003; Andrade et al., 2005; Calis et al., 2016).

The present study was designed to study the toxic effects of MSG on rat pancreas with the possible ameliorative role of TA.

\section{Material and Methods}

Chemicals used in this study included; Monosodium Glutamate powder, tannic acid powder (purchased from Sigma Aldrich Company, Germany), Kits of Pancreatic lipase, amylase, Insulin, and glucose (purchased from Bio diagnostic company, Egypt).

Animals that were used in this study were forty healthy adult white albino rats. They were about 7 weeks old and their weights were $200 \pm 20 \mathrm{gm}$. Animals were purchased from the animal Facility Center of the Faculty of Medicine Helwan University. The animals were housed in animal houses, Faculty of Medicine, Sohag University, in metal cages under ambient temperature, and they were kept under fixed appropriate humidity and light conditions. They were acclimatized to the laboratory condition for one week before starting the treatment protocol. Animals were fed with standard pellet food and water. The protocol was approved by the local ethical committee of the Faculty of Medicine, Sohag University.

At the end of the adaptation period, the rats were weighed and randomly divided into four equal groups, 10 rats each.
Group I (control) received water and diet for 4weeks. Group II (TA) received daily100 $\mathrm{mg} / \mathrm{kg} /$ of TA by oral gavage for 4weeks (Hassan et al., 2011). Group III (MSG) received daily $2 \mathrm{~g} / \mathrm{kg} /$ of MSG by oral gavage which represents $1 / 7$ of oral $\mathrm{LD}_{50}$ for 4weeks (Calis et al., 2016; Sayed et al. 2016). Group IV (TA and MSG) received TA (100 $\mathrm{mg} / \mathrm{kg})$ and $\mathrm{MSG}(2 \mathrm{~g} / \mathrm{kg}) /$ daily by oral gavage for 4 weeks.

At the end of treatment, the animals were sacrificed; blood samples $(3 \mathrm{ml})$ were collected from retro-orbital blood vessels in centrifuge tubes, centrifuged at $4000 \mathrm{rpm}$ for $15 \mathrm{~min}$ and immediately stored at $-20^{\circ} \mathrm{C}$ until their use for biochemical analysis then the animals were dissected to expose the pancreatic organ for histopathological examination.

The biochemical assessment of serum pancreatic enzymes (amylase and lipase) level was estimated by using enzyme-linked immunosorbent assay kits by UV2300 spectrophotometer (The USA). Detection of random blood glucose by spectrophotometer (BAUSCH \& LOMB Spectronic 1001.USA) and plasma insulin level by radioimmunoassay kits (UV2300 spectrophotometer (USA).

Histopathological assessment of the Pancreas included; the pancreas was cleaned with physiological saline and slices from the pancreas were fixed in 10\% neutral formalin. Tissues were processed and prepared for serial paraffin section of $5 \mu \mathrm{m}$ thickness. The slides were stained with hematoxylin and eosin for histopathological examination by Light microscopic with measurement of the pancreatic islet of Langerhans surface area in five high power fields in each animal by image $\mathrm{J}$ software. 


\section{Statistical analysis}

Statistical Package for Social Science (IBM-SPSS), version 24 (May 2016); IBM, Chicago, USA was used for statistical data analysis. The data were expressed as mean \pm standard deviation (SD), number, and percentage. Mean and standard deviation was used as a descriptive value for quantitative data. The Studen's T-test was used to compare the means between two groups, and a One Way analysis of variants (ANOVA) test was used to compare means of more than two groups.

\section{Results}

Table (1) shows a significant increase in the mean values of serum levels of both amylase and lipase enzymes in the studied groups with $p<0.01$ and $p<0.001$ respectivly. On comparing MSG treated group (Group III) to the control group (Group I) there was a significant increase in the mean values of serum levels of amylase and lipase enzymes with $\mathrm{p}<0.01$. However, when TA co administrated to MSG (Group IV) significant improvement was observed in the serum level of amylase enzyme with $p<0.01$ while no significant improvement was detected in the serum level of lipase enzyme with $p>0.05$ as compared to group III.

Table (1): The mean values and standard deviation of pancreatic enzymes in the studied groups $(n=40)$

\begin{tabular}{|l|c|c|c|c|c|c|}
\hline \multirow{2}{*}{$\begin{array}{c}\text { Studied groups } \\
(\mathbf{n}=\mathbf{1 0} \text { rats each) }\end{array}$} & \multicolumn{3}{|c|}{ Serum amylase (U/I) } & \multicolumn{3}{c|}{ Serum lipase (U/l) } \\
\cline { 2 - 7 } & mean \pm SD & p1 & p2 & mean \pm SD & p1 & p2 \\
\hline Control & $2475 \pm 494.7$ & & & $11.71 \pm 3.1$ & & \\
\hline TA & $2335.8 \pm 370.5$ & 0.527 & & $12.33 \pm 2.64$ & 0.673 & \\
\hline MSG & $3209.3 \pm 422$ & 0.005 & & $37.9 \pm 8.9$ & 0.000 & \\
\hline TA +MSG & $2452.4 \pm 417.1$ & 0.926 & 0.002 & $34.57 \pm 5.9$ & 0.000 & 0.403 \\
\hline p-value & \multicolumn{3}{|c|}{$<0.001^{*}$} & \multicolumn{4}{c|}{$<0.001^{*}$} \\
\hline
\end{tabular}

P-value; is for comparison between the groups assessed via ANOVA test, TA; tannic acid, MSG; monosodium glutamate, p1; on comparing control group with other groups, p2; on comparing MSG group with (MAG + TA) groups, data expressed as mean \pm standard deviation (SD), * significant at $\mathrm{p} \leq 0.05, \mathrm{n}$; number.

Regarding random blood glucose, table (2) shows a significant increase in mean values of the blood glucose level in the studied groups with $\mathrm{p}<0.001$. Comparing MSG treated group (Group III) to the control group (Group I), there was a significant increase in the mean values of blood glucose level with $p<0.01$. The combination of TA with MSG (Group IV) revealed a significant reduction in mean values of blood glucose level when compared to Group III. On other hand, a non- significant difference in serum insulin level was observed in all studied animals groups with $p>0.05$. 
Table (2): The mean values and standard deviation of pancreatic function tests in the studied groups $(n=40)$.

\begin{tabular}{|c|c|c|c|c|c|c|}
\hline \multirow{2}{*}{$\begin{array}{l}\text { Studied } \quad \text { groups } \\
\text { (n=10rats each) }\end{array}$} & \multicolumn{3}{|c|}{ Blood glucose (mg/dl) } & \multicolumn{3}{|c|}{ Serum insulin $(\mu \mathrm{U} / \mathrm{ml})$} \\
\hline & mean \pm SD & p1 & $\mathbf{P 2}$ & mean \pm SD & p1 & P2 \\
\hline Control & $112.7 \pm 8.6$ & & & $3.47 \pm 1.4$ & & \\
\hline TA & $113.4 \pm 10.3$ & 0.882 & & $3.0 \pm 1.38$ & 0.512 & \\
\hline MSG & $148 \pm 25.17$ & 0.003* & & $3.7 \pm 1.66$ & 0.771 & \\
\hline TA +MSG & $119.1 \pm 8.59$ & 0.186 & $0.01 *$ & $3.08 \pm 1.6$ & 0.642 & 0.460 \\
\hline p-value & \multicolumn{3}{|c|}{$<0.001 *$} & \multicolumn{3}{|c|}{0.743} \\
\hline
\end{tabular}

P-value: is for comparison between the groups assessed via ANOVA test, TA; tannic acid, MSG; monosodium glutamate, p1: on comparing control group with other groups, p2: on comparing MSG group with (MAG + TA) groups, data expressed as mean \pm standard deviation (SD), * significant at $\mathrm{p} \leq 0.05$, n: number, $\mu \mathrm{U}$ : micro unite.

Regarding the pancreatic surface area size, table (3) shows a significant increase in mean value in the studied groups with $\mathrm{p}<$ 0.001 . The mean value of pancreatic islet area size in MSG treated group (Group III) showed a significant increase when compared to group I with $\mathrm{p}<0.001$ while combined administration of TA with MSG (Group IV) caused a significant reduction in the pancreatic islet area size as compared to group III with $\mathrm{p}<0.001$.

Table (3): Pancreatic surface area size in all studied groups $(n=40)$.

\begin{tabular}{|l|c|c|c|}
\hline \multirow{2}{*}{$\begin{array}{c}\text { Studied groups } \\
(\mathbf{n}=\mathbf{1 0} \text { rats each) }\end{array}$} & Pean \pm SD & p1 & p2 \\
\cline { 2 - 4 } & $519.02 \pm 26.0$ & 0.521 & \\
\hline Control & $564.9 \pm 29.6$ & $0.000^{*}$ & $0.001^{*}$ \\
\hline TA & $3558.5 \pm 974.2$ & $0.001^{*}$ & \\
\hline TA +MSG & $1986.1 \pm 217.54$ & $<0.001^{*}$ & \\
\hline p-value & & \multicolumn{2}{c|}{ Pancreatic surface area size $(\boldsymbol{\mu m})$} \\
\hline
\end{tabular}

P-value: is for comparison between the groups assessed via ANOVA test, p1: on comparing control group other groups, TA; tannic acid, MSG; monosodium glutamate, p2: on comparing MSG group with (MAG + TA) groups, data expressed as mean \pm standard deviation (SD), * significant at $\mathrm{p} \leq 0.05$, $\mathrm{n}$ : number.

Examination of a section of the liver by $\mathrm{H} \& \mathrm{E}$ stain from MSG treated group (Group III) displayed diffuse loss in the normal architecture of the pancreas such as hyperplasia and hypertrophy of islets of Langerhans with a decrease in their numbers. Also, the islet cells showed vacuolated cytoplasm and pyknotic nuclei, as well as the acinar cells, showed mild changes in their normal architecture in addition to congestion and dilation in the blood vessels with the presence of edema in between (Figure 1C) as compared to the control group (Figure 1A). These findings were improved when TA was co administrated to MSG (Group IV) where there was a less or normal appearance in most of the pancreatic architecture with slightly vacuolated cells (Figure 1D) 

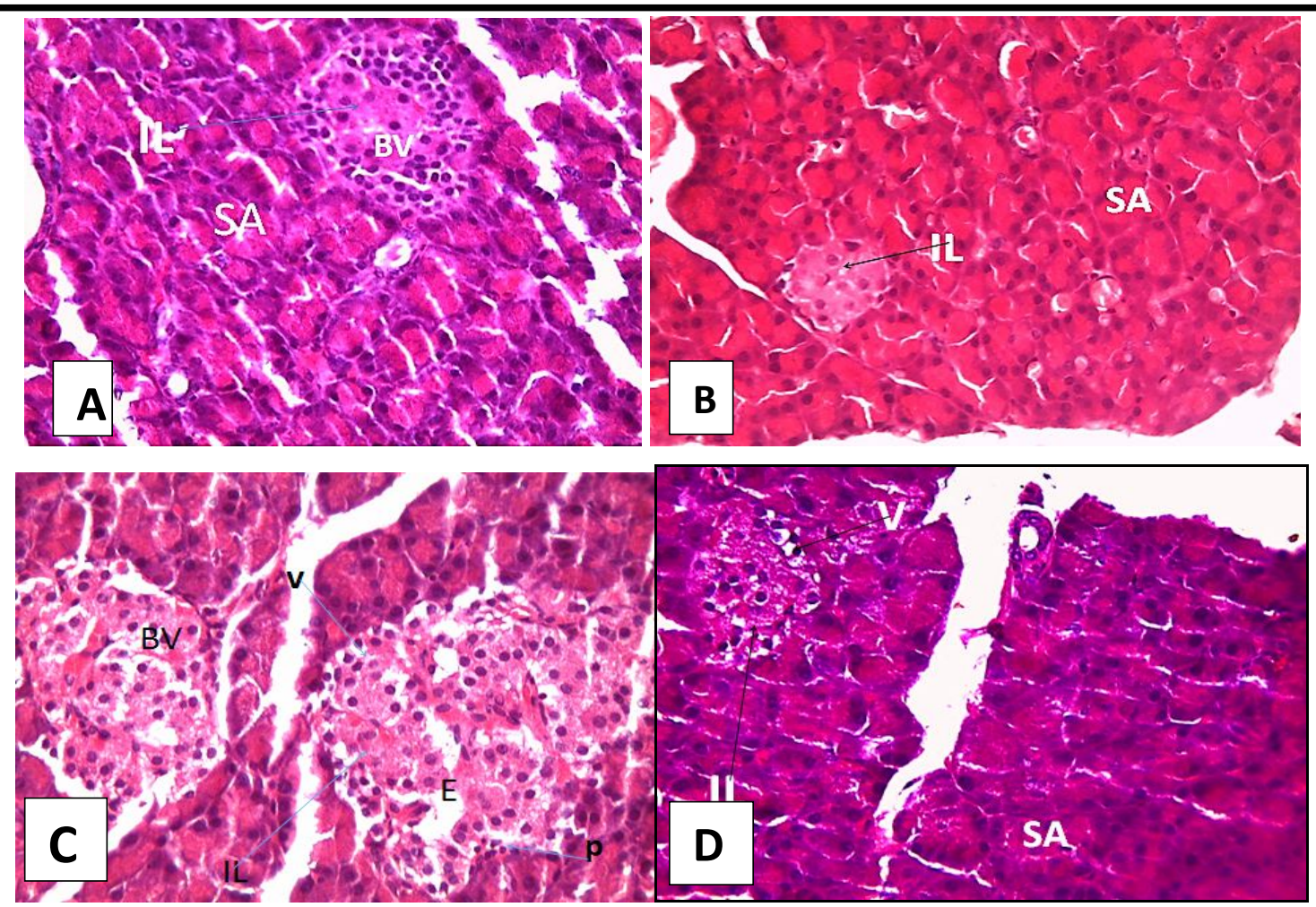

Fig.(1): Microscopic pictures of H\&E stained pancreatic section (A) from groups I showing a normal architecture of the pancreas, the islets of Langerhans (IL) are normal, in between normal pancreatic acini (SA) and normal blood vessels (BV). Also pancreatic section (B) from group II animals showing a normal architecture of the pancreas, normal islets of Langerhans (IL) with normal pancreatic serous acini (SA). while Pancreatic section (C) from group III showing a loss in normal architecture of the pancreas; hyperplasia and hypertrophy of islets of Langerhans (IL) with pyknotic nuclei $(\mathrm{P})$, vaculation $(\mathrm{V})$, and edema $(\mathrm{E})$ with congested dilated blood vessels (BV). Pancreatic section (D) from a group (IV) showing restoration of most pancreatic structure towards the normal, less, or normal islets of Langerhans (IL) and acinar cells are less or normal (SA)with less vaculation (V).

\section{Discussion}

The pancreas is considered one of the organs which are affected by MSG toxicity and its functional efficiency could be determined by measuring the serum level of plasma lipase and amylase enzymes (Mohamed and El-Mandrawy, 2016).

By studying the toxic effect of MSG on pancreatic enzymes, the present study revealed a significant rise in the serum level of amylase and lipase enzymes in MSG treated group which could be attributed to their release into the blood circulation instead of passing through the duct to the intestine.
This might result from the primary effect of oxidative injury of MSG or impaired membrane permeability of the acinar cells (Azevedo-Martins et al., 2003 and Abdulsalam et al., 2018).

The current results were in agreement with Seiva et al. (2012); Abdulsalam et al. (2018) and Moen et al. (2020) who reported significant elevation in the levels of lipase and amylase enzymes in the MSG-treated group compared to the control group.

Contrary to the present study, Yadav et al. (2010) showed that MSG induced a dosedependent inhibitory effect on gastrointestinal alpha-amylase enzyme activity. When the 
author used the following concentrations of MSG; $2 \%, 6 \%, 8 \%$, and $10 \%$, there was inhibition in the enzyme activity levels; 1750 , 1500,1400 , and 600 units respectively compared to the control value of 2800 units.

Regarding the serum insulin, the current study revealed a non-significant difference in the serum insulin level which in harmony with the results conducted by Elshaikh and Abuelgassim (2014) who declared that glutamate caused insulin resistance but in a certain dose $(240 \mathrm{mg} / \mathrm{kg})$ while no significant changes reported in the other two doses $(120 \mathrm{mg} / \mathrm{kg} \& 480 \mathrm{mg} / \mathrm{kg})$. As well, Boonnate et al. (2015) reported no change in serum insulin levels between the MSG-treated group and the control group.

The current findings could be explained by Marquard et al. (2015) and Takahashi et al. (2019) who observed that glutamate potentiates insulin secretion from pancreatic islets at the pharmacological concentrations while when exposed to relatively high concentrations of extracellular glutamate, the endogenous glutamate might topically inhibit insulin secretion from pancreatic islets.

However, Seiva et al. (2012); Leite et al. (2013); and Moen et al. (2020) reported high insulin blood levels with large doses and longer duration in the MSG-treated group when compared to untreated groups.

Blood glucose is controlled by different organs that affect insulin secretion such as the pancreas, liver, and kidneys (Moen et al., 2020). In the current study, there was a significant elevation in random blood glucose level in MSG treated group as compared to the control group.

Bansal et al. (2005) explained their results by induction of the oxidative stress and reduction in the antioxidant enzymes after MSG administration which lead to leakage of glucose from tissues to blood resulted in hyperglycemia.

The current results on harmony with Diniz et al. (2004) and Diniz et al.(2005) who declared that MSG could induce hyperglycemia via its inhibitory effect on growth hormones. Similarly, Soliman (2011) revealed that hyperglycemia observed in the MSG group was a consequence of the increased food intake. Similar findings were noticed by Seiva et al.(2012) and Helal et al. (2017).

On contrary, Boonnate et al. (2015) showed a non-significant difference in glucose levels between control and MSGtreated groups over 9 months of study.

Regarding the histopathological findings, the present study displayed congestion and dilation in the blood vessels with hyperplasia and hypertrophy of islets of Langerhans with decreased in their number also $\beta$-cells showed pyknosis and vaculation as well as a significant increase in pancreatic islet size distribution.

The current results in agreement with earlier studies that declared various changes in pancreatic islets in MSG treated group such as hemorrhages (Boonnate et al., 2015), hypertrophy, and hyperplasia, Sasaki et al. (2009), and Moen et al. (2020) showed various changes in pancreatic islets with congestion and dilatation in the blood vessels

As revealed by Hayashi et al. (2003) glutamate responsible for the regulation of insulin secretion because it is synthesized and released from $\alpha$ cells in the pancreatic islets so it is possible to found vesicular degeneration and necrosis in the pancreatic tissues when exposed to a large dosage of MSG.

The present study in accordance to Nakayama et al. (2003); Ajibade et al. (2015) and Al-hayyali et al. (2020) who found that 
the histopathological pancreatic changes in MSG treated group may be due to either direct or indirect effect by induction hypothalamic lesions.

On contrary, Abdulsalam et al. (2018) revealed that no histopathological changes in $\beta$-islets cells of Langerhans and only congestion of blood vessels of the pancreas in both MSG-treated and non-MSG-control rats were observed.

Oral administration of both TA with MSG in the present study showed a significant reduction in the serum level of pancreatic enzymes (amylase and Lipase) and in blood glucose which reflects the antioxidant role of TA in preventing oxidative damage of the MSG on the pancreatic parameters while no significant effect on plasma insulin was detected.

According to a study conducted by Lou et al. (2018) who reported that TA has antioxidant and $\alpha$-amylase inhibitory activities superior to that of acarbose and gallic acid and scavenging activities power stronger than Tertiary butylhydroquinone (TBHQ).

Babby et al. (2019) reported that TA has an antioxidant defense mechanism against oxidative stress damage through elevation of the reduced glutathione (GHS) levels which is a potent free radical scavenger within the islets of $\beta$-cell of pancreatic tissue and prevent oxidative damage during the diabetic condition.

The present study in agreement with Calis et al. (2016); Babby et al. (2014) and Babby et al. (2019) who revealed that TA possesses antihyperglycemic activity against streptozotocin-induced diabetic rats and restoration of insulin level to normal range.

Seiva et al. (2012) found that combined administration of quercetin (QC) with MSG treated group over 42 days normalized
Insulin, glucose, and amylase enzyme level compared to rats given only MSG.

The observed alterations in the activities of plasma biochemical markers of pancreatic function in the MSG-treated rats despite of mild pathological changes in pancreatic acini could be referred to as possible physiochemical alterations in the pancreatic acini with consequent enzyme leakage.

\section{Conclusion}

The present study concluded that MSG has deleterious effects on the pancreas functionally and morphologically and TA could ameliorate MSG-induced pancreatic toxicity through having anti-oxidants and scavenger activities. In the future, examination and further research of the protective effect of TA on MSG are needed to examine the safety profile of this widely used food additive.

\section{Acknowledgment}

The authors would like to thank all participants for their contribution to this study including animal house technicians and histology technicians.

\section{Conflict of interest}

The authors declare no conflict of interest. 


\section{References}

Abdulsalam, H., Adamu, S., Sambo, S.J., et al. (2018) 'Monosodium glutamateinduced changes on plasma markers of pancreatic function in adult male Wister rats', Sokoto Journal of Veterinary Sciences, 16 (2), p12-27.

Ajibade, A.J., Fakunle, P.B. and Adetunji, M.O. (2015) 'Some effects of monosodium glutamate administration on the histo-architecture of the spleen and pancreas of adult Wistar rats', $J$. Pharm. Biol Sci., 3(2), p39-50.

Al-hayyali, F.M.K., Ali, K.A. and Kareem, Z.S. (2020) 'Oral glycine and l-arginine administration attenuates monosodium glutamate complications on pancreas structure in albino rats' Sys. Rev. Pharm., 11(4), p491- 497.

Andrade, R.G., Dalvi, L.T., Silva, J.M.C., et al. (2005) 'The antioxidant effect of tannic acid on the in vitro coppermediated formation of free radicals', Archive of Biochemistry and Biophysics, 437(1), p1-9.

Azevedo-Martins, A.K., Lortz, S., Lenzen, S., et al. (2003) 'Improvement of the mitochondrial antioxidant defense status prevents cytokine-induced nuclear factor kappa $\mathrm{B}$ activation in insulin-producing cells', Diabetes, 52(1), p93-101.

Babby, A., Elanchezhiyan, C., Suhasini, S. and Chandirasegaran, G. (2014)

'Antihyperglycemic effect of tannic acid in the streptozotocin- induced diabetic rat', International Journal of Current Research, 6 (03), p5396-5398.

Babby, A., Elanchezhiyan, C., Hassan, T. and Naseer, I. (2019) 'Effect of tannic acid on lipid peroxidation and antioxidants status in streptozotocin induced diabetic rats', International
Journal of Recent Scientific Research, 10 (05), p32591-32594.

Bansal, A.K., Bansal, M., Soni, G. and Bhatnagar, D. (2005) 'Protective role of Vitamin $\mathrm{E}$ pre-treatment on $\mathrm{N}$ nitrosodiethylamine-induced oxidative stress in rat liver', Chemico-biolog. Inter., 156(2), p101-111.

Bera, T.K, Kar, S.K., Yadav, P.K., et al. (2017) 'Effects of monosodium glutamate on human health: A systematic review', World J. Pharm Sci., 5(5), p139-144.

Bertolin, T.E., Farias, D., Guarienti, C., et al. (2011) 'Antioxidant effect of phycocyanin on oxidative stress induced with monosodium glutamate in rats', Braz. Arch. Biol. Technol., 54 (4), p733-738.

Boonnate, P., Waraasawapati, S., Hipkaeo, W., et al. (2015) 'Monosodium glutamate dietary consumption decreases pancreatic $\beta$-cell mass in adult Wistar rats', Journal Pone, 10 (6), p114.

Butnariu, M. and Sarac, I. (2019) 'What is sodium glutamate and what effects it has on health', Journal of Applied Biotechnology \& Bioengineering, 6(5), p223-226.

Calis, I.U., Cosan, D.T., Saydam, F., et al. (2016) 'The effects of monosodium glutamate and tannic acid on adult rats', Iran Red Crescent Med. J., 18(10), p1-7.

Leite, N.C., Ferreir, T.R., Rickli, S., et al. (2013) 'Glycolytic and mitochondrial metabolism in pancreatic islets from msg-treated obese rats subjected to swimming training', Cell Physiol Biochem ., 31, p242-256.

Diniz, Y.S., Faine, L.A., Galhardi, C.M., et al. (2005) 'Monosodium glutamate in 
standard and high- fiber diets: metabolic syndrome and oxidative stress in rats', Nutrition, 21, p749-755.

Diniz, Y.S., Fernandes, A.A., Campos, K.E., et al. (2004) 'Toxicity of hypercaloric diet and monosodium glutamate: oxidative stress and metabolic shifting in hepatic tissue', Food Chem. Toxicol., 42, p319-325.

Elshaikh A.F. A and Abuelgassim, A.I. (2014) 'Effect of monosodium glutamate on plasma insulin, glucose levels and toxicity in rats', Agri. Vet. Reser., http://khartoumspace.uofk.edu/handle/1 $23456789 / 9273$

Hayashi, M., Morimoto, R., Yamamoto, A. and Moriyama, Y. (2003) 'Expression and localization of vesicular glutamate transporters in pancreatic islets, upper gastrointestinal tract, and testis', $J$. Histochem. Cytochem., 51, p1375-1390.

Helal, E.G., El-Sayed, R.A., Gomaa, M.H. and El-Gamal, M.S. (2017) 'Effects of some food additives on some biochemical parameters in young male albino rats and the ameliorative role of royal jelly', Egypt J. Hosp. Med., 67, p605- 613.

Hassan, A.M., Sekena, H., Abd El-Aziem, S.H., et al. (2011) 'Antimutagenic effects of tannic acid on somatic and germ cells of rat', Egypt J. Genet. Cytol., 40, p15-29.

Husarova, V. and Ostatnikova, D. (2013) 'Monosodium glutamate toxic effects and their implications for human intake', A Review. JMED Research., p1-12. DOI: 10.5171/2013.608765.

Kumar, S., Kumar, N. and Kumar, B. (2015) 'Evaluation of monosodium glutamate- induced nephrotoxicity in adult Wistar albino rats', World Journal of Pharmacy and Pharmaceutical Sciences, 4(04), p846-862.

Lou, W., Chen, Y., Ma, H., Liang, G. and Liu, B. (2018) 'Antioxidant and aamylase inhibitory activities of tannic acid', J Food Sci Technol., 55(9), p3640-3646.

Marquard, J., Otter, S., Welters, A., et al. (2015) 'Characterization of pancreatic NMDA receptors as possible drug targets for diabetes treatment', Nat. Med., 21(4), p363-372.

Moen, S.S., Elhalwag, M.E.A. and Ayaz, N.O. (2020) 'Alteration in the pancreas of rats treated with individual and combined food additives', Medical Science, 24 (103), p1544-1552.

Mohamed, W. and El-Mandrawy, S. (2016) 'Functional and cellular exocrine pancreatic dysfunction in male mice following sub-chronic exposure to melamine and formaldehyde', Annals of Clinical Pathology, 4(5), p1080.

Nakayama, D., Magami, Y., Azuma, T., et al. (2003) 'Turnover of acinar and islet cells in the pancreas of monosodium glutamate-treated obese mice', Obesity Research, 11(1), p 87-93.

Omar, H.M., Hassan, K.A., Abd-Elghaffar, S.K.H. and Ahmed, E.A. (2003) 'Aluminum toxicity in rats: The role of tannic acid as antioxidant', Ass. Univ. Bull. Environ. Res., 6(2), p 1-14.

Sasaki, Y., Suzuki, W., Shimada, T., Iizuka, S., et al. (2009) 'Dose dependent development of diabetes mellitus and non-alcoholic steatohepatitis in monosodium glutamate-induced obese mice', Life Sciences, 85, p490-498. 
Seiva, F.F.R., Chuffa, L.A.G., Braga, C.P., et al. (2012) 'Quercetin ameliorates glucose and lipid metabolism and improves antioxidant status in post natally monosodium glutamate-induced metabolic alterations', Food and Chemical Toxicology, (50), p35563561 .

Soliman, A.M. (2011) 'Extract of coelatura aegyptiaca, a freshwater clam, ameliorates hepatic oxidative stress induced by monosodium glutamate in rats', African Journal of Pharmacy and Pharmacology, 5(3), p398-408.

Sharma, V. and Deshmukh, R. (2015) 'Ajimomoto (Msg): a fifth tatse or a bio bomb', European Journal of Pharmaceutical and Medical Research, 2(2), p381-400.

Shukry, M., El-Shehawi, A.M., El-Kholy, W.M., et al. (2020) 'Ameliorative effect of graviola (annona muricata) on mono sodium glutamate-induced hepatic injury in rats: antioxidant, apoptotic, anti-inflammatory, lipogenesis markers, and histopathological studies', Animals, 10(1996), p1-19.

Sayed, H.M.Y., Abd-Elhalim, D.M., Mona, A., et al. (2016) 'Monosodium glutamate-induced cerebellar toxicity; possible role of nitric oxide in adult albino rats', Journal of American Science, 12 (1), p123-131.

Takahashi, H., Yokoi, N. and Seino, S. (2019) 'Glutamate as intracellular and extracellular signals in pancreatic islet functions', Proc. Jpn. Acad., 95, p246260.

Waer, H.F., and Edress, S. (2006) 'The effect of monosodium glutamate (MSG) on rat liver and the ameliorating effect of "guanidino ethane sulfonic acid (ges)" (Histological, Histochemical and electron microscopy studies)', The Egyptian Journal of Hospital Medicine, 24: p524-538.

Yadav, J.K., Kumar, R.V., Chauhan, J. and Smitha Grace, S.S. (2010) 'Effect of monosodium glutamate (MSG) on alpha-amylase activity R. BCAIJ., 4(2): p81-85. 


\section{الدور التحسني لحمض التانيك في السمية البنكرياسية التي يسببها الجلوتامات أحادي الصوديوم على الجرذان البيضائ}

بلقيس احمد محمل ، شرين احمد محمله ،رانيا احمل رضوان, سهير علي محمد,

$$
\text { ' قسم الطب الثرعى و السموم الاكلينيكية، كلية الطب،جامعة سوهاج }
$$

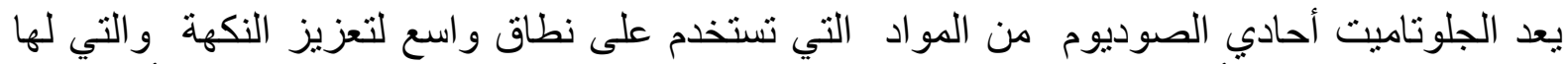

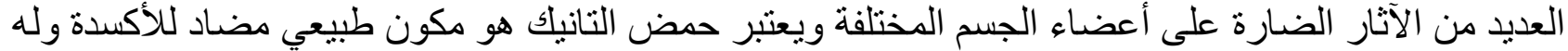

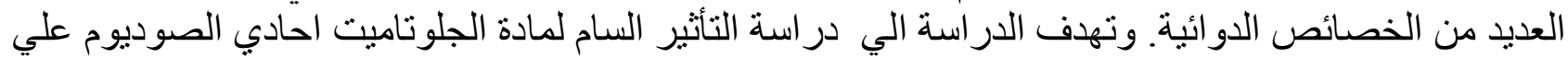
البنكرياس و التاثير التحسني لحمض التانيك حيث.تم اجراء البحث على عدد • ع من ذكور الجرذان البيضاء

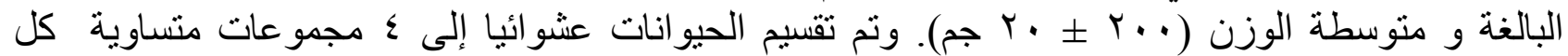
مجموعة تضم • 1 جرذان. المجموعة الاولي: كانت المجموعة الضابطة وتمة وتم تغذيتها بالطعام و الماء فقط.

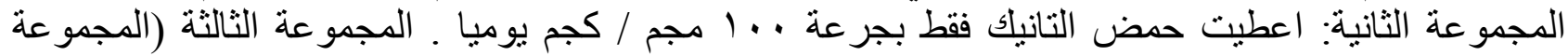

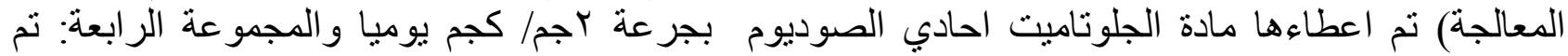

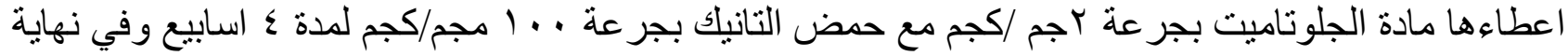

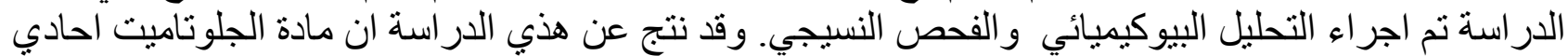

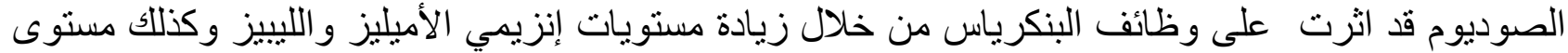

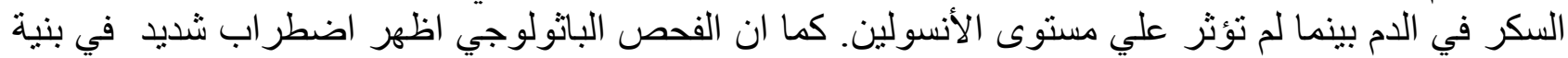

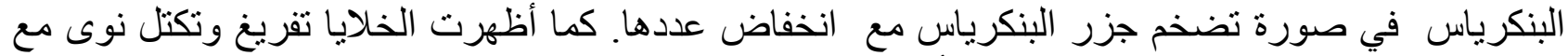

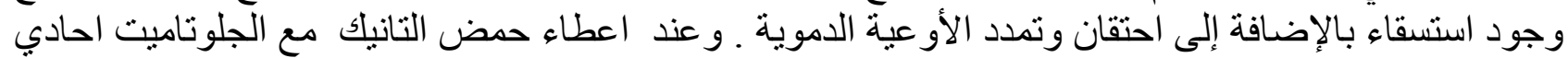

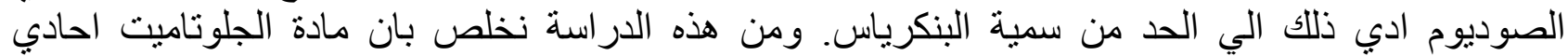

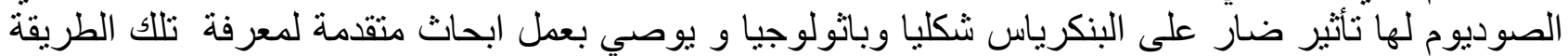

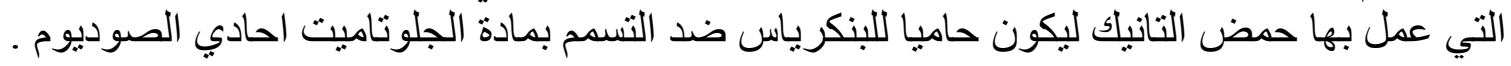

